\title{
Educating the general public about multifactorial genetic disease: applying a theory-based framework to understand current public knowledge
}

\author{
Chris M. R. Smerecnik, MSc, Ilse Mesters, PhD, Nanne K. de Vries, PhD, and Hein de Vries, PhD
}

\begin{abstract}
The present article describes the application of a theory-based framework to understand current public knowledge of genetic risk factors of multifactorial diseases. The main innovative aspect is the application of $\mathrm{E}$. M. Rogers' knowledge framework which distinguishes three types of knowledge: "awareness knowledge," "how-to knowledge," and "principles knowledge." We argue that distinguishing these types of knowledge allows for a more sophisticated overview of the general public. To illustrate the application of Rogers' framework, we performed a literature review of current public knowledge of genetic risk factors of multifactorial genetic diseases. Relevant articles were identified by searching the Pubmed, Web of Science, Embase, CINAHL, ERIC, and PsycINFO databases from January 1990 until January 2007 and by performing reference list and author searches. Although this review showed that current public knowledge is limited, it also showed that the knowledge framework may be a useful tool for assessing different types of public knowledge and pinpointing flaws or caveats in public knowledge with more precision and subsequently develop public health campaigns to remedy such flaws. Implications for genetic education are discussed. Genet Med 2008:10(4):251-258.
\end{abstract}

Key Words: general public, genetic risk, awareness, knowledge, multifactorial disease

As genetic science evolves, genetic predispositions to medical conditions are increasingly better understood. The completion of the Human Genome Project in 2003 has vastly increased professional knowledge of genetics. ${ }^{1}$ The discovery of so-called polymorphisms (i.e., genetic variants) has broadened the scope of genetic risks from single-gene disorders to multifactorial diseases. ${ }^{2}$ These advances in the understanding of genetic predispositions to disease have several implications for public health promotion ${ }^{3}$; the most obvious being whether and how to use genetic information to promote public health. ${ }^{4}$ Investigating public understanding of genetic information is therefore an important dimension of the translation of professional genetic knowledge into public health benefits. ${ }^{5}$

Because knowledge is considered one of the prerequisites of health behavior, ${ }^{6-8}$ a necessary first step in public health promotion involves increasing the general public's knowledge of the genetic risk factors of multifactorial diseases. ${ }^{1}$ E. M. Rogers'

From the School for Public Health and Primary Care (Caphri), Department of Health Education and Promotion, Faculty of Health, Medicine and Life Sciences, Maastricht University, The Netherlands.

Chris Smerecnik, School for Public Health and Primary Care (Caphri), Department of Health Education and Health Promotion, Faculty of Health, Medicine and Life Sciences, Maastricht University, PO Box 616,6200 MD Maastricht, The Netherlands.E-mail: c.smerecnik@ gvo.unimaas.nl.

Disclosure: The authors declare no conflict of interest.

Submitted for publication October 18, 2007.

Accepted for publication January 10, 2008.

DOI: 10.1097/GIM.0b013e31816b4ffd conceptualization of knowledge distinguishes three types of increasingly complex knowledge: "awareness knowledge," which refers to knowledge about the existence of an innovation; "how-to knowledge," which is practical knowledge concerning the proper use of an innovation; and "principles knowledge," or knowledge of the underlying theoretical principles of the innovation. ${ }^{9}$ Although increasing awareness knowledge is an important first step, public health programs should not neglect the other two forms of knowledge. Indeed, if how-to knowledge is not acquired before or during the adoption of the innovation, discontinuance is highly likely. ${ }^{9}$

Although a considerable body of literature has shown the value of this knowledge framework in understanding public knowledge of technical innovations, ${ }^{10,11}$ there is relatively scarce research on the value of this framework for the diffusion of new knowledge or ideas. We propose that Rogers' knowledge framework is a valuable asset to the diffusion of (professional) knowledge of genetic risk factors for two reasons. First, the distinction between awareness, how-to, and principles knowledge presents a sophisticated overview of public knowledge of genetic risk factors. Second, it allows us to pinpoint caveats in the public's knowledge with more precision and adapt future public health campaigns to remedy them with appropriate strategies.

In the case of diffusing professional knowledge of genetic risk factors, awareness knowledge refers to simply knowing that there are genetic risk factors of a particular disease. This type of knowledge may act as a motivator to acquire how-to and principles knowledge. ${ }^{9}$ For instance, knowing of the existence of genetic risk factors can motivate individuals to assess 
Table 1

Inclusion and exclusion criteria

\begin{tabular}{ll}
\hline Inclusion criteria & Exclusion criteria \\
\hline $\begin{array}{l}\text { Studies should focus on awareness, how-to, or principles knowledge } \\
\text { of genetic risk factors of multifactorial diseases }\end{array}$ & Examined knowledge of inheritance and genetics in general \\
$\begin{array}{l}\text { Participants should be representative of the general population without being } \\
\text { specifically educated about genetic risk factors by professionals }\end{array}$ & $\begin{array}{l}\text { Participants are individuals who know they have a genetic predisposition } \\
\text { or have attended genetic counseling or other education about genetic } \\
\text { risk factors }\end{array}$ \\
Studies should describe original articles published in a peer-reviewed journal & $\begin{array}{c}\text { Concerned editorials, commentaries, book reviews, bibliographies, } \\
\text { resources, or policy documents } \\
\text { Reported secondary data analysis or only reviewed other studies }\end{array}$ \\
\hline
\end{tabular}

their family history or opt for genetic counseling and testing. ${ }^{12}$ Knowing of the existence of genetic risk factors of a certain disease, however, does not guarantee adequate use of professional knowledge of genetic risk factors in decision-making concerning preventive behavior (e.g., assessing family history or changing unhealthy lifestyles). To this end, how-to knowledge is needed. How-to knowledge refers to practical knowledge of genetic risk factors, such as knowing how genetic risk factors influence the overall risk of developing the disease (e.g., knowing that there is no one-on-one relationship between genetic risk and disease development).

In contrast, principles knowledge refers to theoretical knowledge of genetic risk factors, such as knowledge of the underlying working mechanisms through which genetic risk factors affect disease development (e.g., knowing that certain polymorphisms create a genetic predisposition that interacts with other factors to develop the disease). Although adequate decision-making can occur without proper principles knowledge, the risk of falsely using perceived knowledge of genetic risk factors in decision-making is substantially higher without it. ${ }^{9}$ For instance, a flawed or speculative understanding of how a disease can be genetic if the disease has not yet been observed in the family (as could be the case in recessive disorders or certain polymorphisms) has been shown to adversely affect health behavior. ${ }^{13,14}$

The general public thus needs to know that polymorphisms interact with other genes and environmental factors, such as lifestyle, to cause the development of the disease. ${ }^{15}$ Understanding the complexity of gene-environment interactions (i.e., how and why genetic risk factors affect the development of multifactorial diseases) may prevent feelings of fatalism caused by unchangeable genetic predispositions and increase motivation to change unhealthy lifestyles, both in the absence, but especially in the presence of a genetic predisposition. Despite the importance of such knowledge for adequate preventive behavior, little research has focused on the general public's knowledge of genetic risk factors and how and why these factors affect health. ${ }^{16}$ However, future health promotion programs intended to increase public knowledge of genetic risk factors for multifactorial diseases are likely to be unsuccessful if they disregard the public's prior knowledge. ${ }^{17}$

We propose in this article that applying Rogers' knowledge framework to map current public knowledge of genetic risk fac- tors of multifactorial diseases will provide us with valuable insights on the structure of public knowledge as well as guide and assist future research and public education about multifactorial genetic disease. To illustrate the application of Rogers' framework, we performed a literature review of the general public's current knowledge of genetic risk factors of multifactorial diseases. The value of Rogers' knowledge framework will be discussed in light of the results of this review.

\section{MATERIALS AND METHODS}

\section{Search strategy}

Literature searches were conducted in the Pubmed, Web of Science, Embase, CINAHL, ERIC, and PsycINFO databases from January 1990 until January 2007. The following keywords were exhaustively combined: awareness, knowledge, general public, general population, community, lay understanding, genetic risk, familial risk, multifactorial disease, and genetic risk factors. Further, we also performed reference list and author searches. Table 1 specifies the inclusion criteria used to identify relevant studies.

\section{Study selection}

The selection process was completed in three separate phases. During the first phase, articles were selected or excluded based on their titles only. Studies selected for further review and those that could not be excluded without doubt proceeded to the second phase of the review process. Articles judged relevant based on their abstracts were included in the present review; those deemed irrelevant were excluded. In the third and final phase of the selection process, the remaining articles were exhaustively reviewed for content.

We included articles that examined awareness, how-to, or principles knowledge of genetic risk factors of multifactorial diseases among the general public. Articles were excluded if they examined knowledge of genetics in general or knowledge of genetic risk factors among individuals attending genetic counseling clinics. From an initial sample of 1174 eligible articles, we selected 20 for the present review. Because of the heterogeneity of the studies, we opted against pooling the data and thus against a meta-analysis of these studies. Relevant data were abstracted and summarized in Tables 2 and 3. 
Table 2

Studies examining the general public's awareness knowledge of genetic risk factors of multifactorial diseases

\begin{tabular}{|c|c|c|c|c|c|}
\hline Study & Country & Design & Sample & Disease & Outcome \\
\hline Ackermann et al. ${ }^{19}$ & Germany & Quantitative & $\begin{array}{l}2108 \text { women of } 23 \\
\text { gynecological } \\
\text { outpatient services }\end{array}$ & Cervical cancer & $\begin{array}{l}\text { 93.3\% identified genetic risk factors of cervical } \\
\text { cancer }\end{array}$ \\
\hline Bottorff et al. ${ }^{43}$ & Canada & Quantitative & $\begin{array}{l}761 \text { women without } \\
\text { family history and } \\
260 \text { women with a } \\
\text { family history }\end{array}$ & Breast cancer & $\begin{array}{l}\text { Approximately } 80 \% \text { of each group was aware } \\
\text { of the existence of breast cancer genes }\end{array}$ \\
\hline Bruno et al. ${ }^{44}$ & Italy & Quantitative & $\begin{array}{l}677 \text { healthy women with } \\
\text { or without a family } \\
\text { history }\end{array}$ & Breast cancer & $\begin{array}{l}\text { 77\% self-reported having heard about the } \\
\text { existence of breast cancer genes. Women } \\
\text { with and without a family history did not } \\
\text { differ with regards to awareness of the } \\
\text { existence of breast cancer genes }\end{array}$ \\
\hline Hunt et al. ${ }^{45}$ & England & Qualitative & $\begin{array}{l}61 \text { men and women } \\
\text { from middle and } \\
\text { working class were } \\
\text { selected from a large } \\
\text { cross-sectional survey } \\
\text { and subsequently } \\
\text { interviewed }\end{array}$ & Heart disease & $\begin{array}{l}\text { More than two thirds spontaneously } \\
\text { mentioned genetic risk factors }\end{array}$ \\
\hline Keighley et al. ${ }^{46}$ & $\begin{array}{l}21 \text { European } \\
\text { countries }\end{array}$ & Quantitative & $\begin{array}{l}20,710 \text { individuals over } \\
16 \text { years of age } \\
\text { representative of } \\
\text { general population in } \\
\text { Europe }\end{array}$ & Colorectal cancer & $\begin{array}{l}54 \% \text { was aware of the genetic risk factor of } \\
\text { colorectal cancer }\end{array}$ \\
\hline Mogilner et al. ${ }^{20}$ & The United States & Quantitative & $\begin{array}{l}354 \text { female patients of } \\
\text { Mount Sinai Medical } \\
\text { Center }\end{array}$ & Breast cancer & $\begin{array}{l}\text { Overall, approximately } 50 \% \text { was aware of } \\
\text { BRCA1/2 genes. Participants of African- } \\
\text { American descent (19\%) and those who } \\
\text { only completed elementary school (13\%) } \\
\text { were relatively unaware compared } \\
\text { with whites (68\%) and those who completed } \\
\text { graduate school }(71 \%)\end{array}$ \\
\hline Morris et al. ${ }^{47}$ & The United States & Quantitative & $\begin{array}{l}2353 \text { individuals } \\
\text { contacted in a } \\
\text { national survey }\end{array}$ & $\begin{array}{l}\text { Four environmentally } \\
\text { induced conditions }\end{array}$ & $\begin{array}{l}\text { Public awareness of genetic risk factors of } \\
\text { environmentally induced conditions was } \\
\text { limited; } 32 \% \text { is unaware of genetic risk } \\
\text { factors of environmentally induced } \\
\text { conditions }\end{array}$ \\
\hline Tambor et al. ${ }^{21}$ & The United States & Quantitative & $\begin{array}{l}473 \text { women without an } \\
\text { increased risk of } \\
\text { breast cancer }\end{array}$ & Breast cancer & $\begin{array}{l}51 \% \text { was aware of the existence of breast } \\
\text { cancer genes. Lower-educated individuals } \\
\text { (less than high school) were } 2.5 \text { times less } \\
\text { likely to be aware of genetic risk factors }\end{array}$ \\
\hline $\begin{array}{l}\text { Van den Nieuwenhoff } \\
\text { et al. } .^{22}\end{array}$ & The Netherlands & Quantitative & $\begin{array}{l}4117 \text { individuals } \\
\text { representative of the } \\
\text { general population }\end{array}$ & $\begin{array}{l}\text { Inherited high } \\
\text { cholesterol }\end{array}$ & $\begin{array}{l}50 \% \text { was aware of inherited high cholesterol. } \\
\text { Higher-educated individuals were more } \\
\text { aware than lower-educated individuals }(\mathrm{OR}= \\
1.73, P<0.001) \text {. Women were more } \\
\text { likely to be aware than men }(\mathrm{OR}=1.40, \\
p<0.001) \text {. }\end{array}$ \\
\hline Waller et al. ${ }^{18}$ & Great Britain & Quantitative & $\begin{array}{l}1940 \text { individuals } \\
\text { representative of the } \\
\text { British population }\end{array}$ & Cervical cancer & $\begin{array}{l}17.6 \% \text { reported genetic factors as playing a } \\
\text { role in the development of cervical cancer. } \\
\text { Higher-educated individuals were more } \\
\text { aware of genetics as a risk factor }(23.3 \%) \\
\text { than lower-educated individuals }(11.4 \%) \text {. } \\
\text { Women were more aware than men }(19.9 \% \\
\text { vs. } 14.5 \%)\end{array}$ \\
\hline Wardle et al. ${ }^{48}$ & Great Britain & Quantitative & $\begin{array}{l}3693 \text { adults } \\
\text { representative of the } \\
\text { British population }\end{array}$ & Cancer & $\begin{array}{l}\text { Awareness of genetic risk factor was relatively } \\
\text { low compared with awareness of other risk } \\
\text { factors: approximately } 50 \% \text { was aware of } \\
\text { the genetic risk factor of breast cancer to } \\
\text { approximately } 22 \% \text { for lung cancer }\end{array}$ \\
\hline Welkenhuysen et al. ${ }^{49}$ & Belgium & Quantitative & $\begin{array}{l}329 \text { women from } \\
\text { Flemish Belgium }\end{array}$ & Breast cancer & $\begin{array}{l}79 \% \text { reported being aware of hereditary breast } \\
\text { cancer }\end{array}$ \\
\hline
\end{tabular}


Table 3

Studies examining the general public's how-to and principles knowledge of genetic risk factors of multifactorial diseases

\begin{tabular}{|c|c|c|c|c|c|}
\hline Study & Country & Design & Sample & Disease & Outcome \\
\hline Bates et al. ${ }^{24}$ & The United States & Qualitative & $\begin{array}{l}108 \text { individuals from urban, } \\
\text { suburban, and rural } \\
\text { communities in Georgia } \\
\text { were interviewed }\end{array}$ & Heart disease & $\begin{array}{l}\text { Overall, participants perceived genetic } \\
\text { predisposition to mean heightened } \\
\text { but not absolute risk and result in } \\
\text { an increased risk of becoming sick }\end{array}$ \\
\hline Bottorff et al. ${ }^{43}$ & Canada & Quantitative & $\begin{array}{l}761 \text { women without family } \\
\text { history and } 260 \text { women } \\
\text { with a family history }\end{array}$ & Breast cancer & $\begin{array}{l}\text { Knowledge was relatively limited } \\
\text { (mean }=4 \text { on a } 0-7 \text { scale). Women } \\
\text { with a family history did not show } \\
\text { superior knowledge compared with } \\
\text { women in the general public }\end{array}$ \\
\hline De Vries et al. ${ }^{28}$ & The Netherlands & Quantitative & 457 Dutch adults & Cancer & $\begin{array}{l}\text { Although the majority of participants } \\
\text { recognized that genetic risk factors } \\
\text { increase, but do not determine } \\
\text { cancer development, they } \\
\text { overestimated the role of these } \\
\text { factors (52\%) and how they cause } \\
\text { the development of cancer. Higher- } \\
\text { educated individuals had more } \\
\text { knowledge of how genetic risk } \\
\text { factors cause cancer than lower- } \\
\text { educated individuals }\end{array}$ \\
\hline Donovan and Tucker ${ }^{23}$ & The United States & Quantitative & $\begin{array}{l}220 \text { women awaiting } \\
\text { routine medical services }\end{array}$ & Breast cancer & $\begin{array}{l}\text { Knowledge about how genetic risk } \\
\text { factors affect risk (mean }=7 \text { on a } \\
0-14 \text { scale) was less than knowledge } \\
\text { about other risk factors (mean }=12 \\
\text { on a } 0-18 \text { scale). Whites had more } \\
\text { knowledge than African Americans } \\
\text { (7.7 vs. } 7.0, P=0.02) \text {. }\end{array}$ \\
\hline Henneman et al. ${ }^{29}$ & The Netherlands & Quantitative & $\begin{array}{l}817 \text { individuals from a } \\
\text { Dutch consumer panel }\end{array}$ & Not specified & $\begin{array}{l}\text { Most of the participants had adequate } \\
\text { knowledge of genetic risk factors. } \\
\text { Higher-educated individuals and } \\
\text { men had more knowledge than } \\
\text { lower-educated individuals and } \\
\text { women }\end{array}$ \\
\hline Inoue et al. ${ }^{25}$ & Japan & Quantitative & $\begin{array}{l}1355 \text { individuals } \\
\text { representative of general } \\
\text { population }\end{array}$ & Cancer & $\begin{array}{l}\text { Participants accurately perceived } \\
\text { genetic predisposition as resulting } \\
\text { in heightened risk of developing } \\
\text { cancer }\end{array}$ \\
\hline McMenamin et al. ${ }^{27}$ & Ireland & Quantitative & $\begin{array}{l}1250 \text { women and } 1105 \text { men } \\
\text { from the general } \\
\text { population }\end{array}$ & Breast cancer & $\begin{array}{l}\text { The majority of the participants } \\
\text { accurately reported increased risk } \\
\text { due to genetic risk factors ( } 77 \% \text { of } \\
\text { the men and } 92 \% \text { of the women) }\end{array}$ \\
\hline Mesters et al. ${ }^{26}$ & The Netherlands & Qualitative & $\begin{array}{l}40 \text { women and } 9 \text { men were } \\
\text { interviewed }\end{array}$ & Cancer & $\begin{array}{l}\text { Although participants recognized the } \\
\text { increased risk due to genetic risk } \\
\text { factors, their knowledge of the } \\
\text { working mechanisms of genetic } \\
\text { factors was (highly) inadequate }\end{array}$ \\
\hline
\end{tabular}

\section{RESULTS}

\section{Awareness knowledge of genetic risk factors}

According to Rogers' suggestion, the first phase of public health education should focus on increasing awareness of the existence of the genetic risk factors of multifactorial diseases. Several studies have examined public awareness of the genetic risk factors of many multifactorial diseases in a wide variety of countries (Table 2). Overall, these studies suggest that the general public is reasonably aware of the genetic risk factors of multifactorial diseases, with approximately 59\% (range, 17.6$93.3 \%$ ) of the sample being aware of the existence of genetic risk factors, although much lower ${ }^{18}$ and much higher ${ }^{19}$ proportions have also been observed.

Most studies, however, showed differences in public awareness of the genetic risk factors for different types of cancer. For instance, on average, approximately $60 \%$ was aware of the genetic risk factors for breast cancer, whereas some studies observed that only approximately $20 \%$ was aware of the genetic risk factors of cervical cancer. Because we were not able to identify more than one study examining public awareness of heart disease, environmentally induced conditions, and hypercholesterolemia, we were unable to draw any conclusions regarding public awareness of these conditions. 
Several studies observed that awareness of genetic risk factors of multifactorial diseases is highly dependent on sociodemographic factors. For instance, individuals with low educational levels were less aware of genetic risk factors compared with highly educated individuals. ${ }^{18,20-22}$ African Americans were less likely to be aware of genetic risk factors than whites, ${ }^{20}$ and women were more aware than men. ${ }^{18,22}$

The studies reviewed here show a mixed view of public awareness of genetic risk factors of multifactorial diseases, with little over half the population being aware of the existence of such risk factors. The overall picture may, however, be somewhat poorer, because being aware of genetic risks factors does not guarantee a clear understanding of how they influence health.

\section{How-to knowledge of genetic risk factors}

Although public knowledge of genetics has been relatively little investigated, ${ }^{16}$ a few studies have examined the public's knowledge of the genetic risk factors of multifactorial diseases (Table 3). With regards to how-to knowledge, the central question concerns whether the general public has practical knowledge of genetic risk factors and how they influence the risk of development of multifactorial disease. The few studies examining this type of knowledge show that the general public's knowledge seems limited. For instance, Donovan and Tucker ${ }^{23}$ observed that the public has limited knowledge on how genetic risk factors influence health, especially when compared with other risk factors. However, the general public does seem to understand that having a genetic predisposition implies heightened, but not absolute risk. ${ }^{24-27}$

In line with the studies on the general public's awareness of genetic risk factors, these studies seem to suggest that knowledge of how the genetic risk factors of multifactorial diseases affect health is largely dependent on sociodemographic factors, such as ethnicity, ${ }^{23}$ gender, ${ }^{27}$ and level of education. ${ }^{28,29}$

\section{Principles knowledge of genetic risk factors}

Principles knowledge is the most complex form of knowledge, focusing on theoretical issues such as why genetic risk factors affect the development of multifactorial diseases in the way they do. Only one study has examined the public's principles knowledge: Mesters et al. ${ }^{26}$ observed that although participants recognized the increased risk owing to genetic risk factors, their knowledge of the working mechanisms of genetic factors was (highly) inadequate. Because participants associated cancer with faulty cells, they were unable to distinguish between the genetic aspect of cancer and the "faulty cell." Mesters et al. concluded that the general public's principles knowledge is largely insufficient and superficial.

\section{DISCUSSION}

The present review shows that the general public has limited awareness knowledge of genetic risk factors as a cause of multifactorial disease and even less knowledge of how and why these factors affect health. On average, just over half the re- search sample was aware of the existence of genetic risk factors of multifactorial diseases (i.e., awareness knowledge). Furthermore, although the public seems to understand that having a genetic predisposition means heightened and not absolute risk, they seem to have limited how-to and principles knowledge of genetic risk factors.

We should note that the studies we reviewed were not conducted with Rogers' framework of knowledge in mind. Our analysis of the potential utility of the knowledge framework is thus limited to the pooled data. Although most studies did distinguish awareness from general knowledge, we argue that distinguishing knowledge into awareness, how-to, and principles knowledge allows for a more detailed picture of the general public's knowledge. The distinction between awareness, (practical) how-to, and (theoretical) principles knowledge depicts a knowledge continuum representing an increasingly complex form of knowledge. This continuum, ranging from being aware of the existence at one end to knowing the underlying mechanisms of genetics at the other end, allows us to better map public knowledge and enables us to set a threshold amount of knowledge the public ought to possess to accurately process new information. Unfortunately, we were not able to identify such a threshold, partly owing to the fact that the original studies were not conducted with the Rogers' framework in mind. Future research examining the general public's knowledge of genetic risk factors using Rogers' knowledge framework will be able to do just that. Moreover, the knowledge framework will also allow us to pinpoint flaws or caveats in public knowledge with more precision and subsequently develop public health campaigns to remedy such flaws. Indeed, our results suggest that the public's how-to knowledge is limited, whereas the public's principles knowledge is largely insufficient; a finding that would not have been observed using only the awareness-knowledge distinction.

Moreover, recent research has shown that individuals implicitly make a distinction between practical how-to knowledge and theoretical principles knowledge. ${ }^{30,31}$ Several studies have shown that individuals were only interested in the consequences of genetic risk factors and how to manage them, and were not at all interested in the underlying genetic principles. ${ }^{30}$ Similarly, the public has no need for detailed information on the working mechanism of DNA, but is interested in more practical knowledge of the role of genetics in the development of cancer (e.g., identifying the signs of a genetic predisposition to cancer). ${ }^{31}$ Such general lack of interest in the theoretical mechanisms of genetic risk factors until such knowledge is relevant $^{26}$ (e.g., when diagnosed with a family history) may also explain why the general public's principles knowledge is largely insufficient. More importantly, however, these issues suggest that the knowledge framework is a useful tool to understand the general public's knowledge of genetic risk factors.

Perhaps unsurprisingly, awareness, how-to, and principles knowledge seem to be largely dependent on sociodemographic factors, such as ethnicity, gender, and level of education. Ethnic minorities and lower-educated individuals seem to have less knowledge than whites and higher-educated individuals. ${ }^{32}$ 
Although these results do not add to the existing literature, they do highlight the resulting caveat in current public health promotion practices. More specifically, although the dissemination of genetic information to the general public has received considerable attention in the last decade, ${ }^{3}$ the present results on the relationship between sociodemographics and knowledge suggest that professional knowledge on genetic predispositions may not yet have been equally disseminated. Our results suggest that the diffusion of genetic knowledge should especially focus on ethnic minorities and the lower-educated segment of the population, because it is these which seem to lag behind.

The translation of genetic knowledge from the professional to the layman, however, "goes beyond mere dissemination and/or diffusion." 33 Knowledge translation is a complex process, which is, at least partly, due to the complexity and incompleteness of genetic knowledge itself. Indeed, even among health educators ${ }^{34}$ and medical experts ${ }^{35-37}$ knowledge of genetics is surprisingly low. Consequently, it may be argued that the observed differences in knowledge between lower- and higher-educated individuals may not only be due to incomplete dissemination, but also to the complexity of the disseminated information. Indeed, lower-educated individuals have more difficulty understanding genetic information than highereducated individuals, ${ }^{38}$ which can also be seen from our results. Moreover, this perceived difficulty of genetic information may discourage lower-educated individuals from even attempting to process genetic messages.

Because our review suggests that ethnic minorities and lowereducated individuals are the least knowledgeable and have more difficulties understanding genetic information, we suggest special attention be paid to both the dissemination of genetic knowledge to these segments and their abilities to understand genetic information. One possibility would be to simplify the information without changing its meaning. However, because other factors (e.g., the relevance of the information) beyond its complexity may also influence behavior or decision-making, we first need to understand the different ways by which the public processes such information. ${ }^{33}$

Recent research in this area suggests that the public has at least some understanding of genetics in general. For instance, Lanie et al. ${ }^{39}$ observed that the public seems to understand to some extent the gene-environment interaction underlying the development of multifactorial diseases. Alarmingly, however, they also observed general confusion about basic terms such as "genes" and "genetics," and argued that such confusion may adversely impact public understanding of more complex genetic messages (also see the 2002 World Health Organization report on Genomics and World Health ${ }^{2}$ ). These misconceptions may also explain our finding that the public's how-to and principles knowledge is limited and superficial. Indeed, research has shown that misconceptions about basic genetic terms may lead to incorrect processing of new information about genetic risk factors for multifactorial diseases, especially when individuals are unaware of their misconceptions. ${ }^{40,41}$
These issues raise the question of whether informing the general public about genetic risk factors of multifactorial diseases is an effective strategy in promoting public health. Although knowledge of such factors can potentially serve as a cue to action or otherwise motivate individuals to engage in preventive behavior, it may not contribute to preventive behavior over and above knowledge of other risk factors in high-risk individuals. ${ }^{42}$ Furthermore, for previously unaware individuals, information on the existence of genetic risk factors actually decreases perceived susceptibility, and as a result, leads to lower motivation to engage in preventive behavior (unpublished data, 2007). In promoting public health, one should therefore not focus on increasing awareness knowledge alone, which may produce adverse effects, but at the same time increase understanding of how and why genetic risks influence the development of multifactorial diseases.

Unfortunately, our results suggest that increasing awareness knowledge is the outcome of recent public health campaigns. In other words, although the general public has reasonable awareness knowledge, they lack adequate how-to and principles knowledge. On the one hand, previous campaigns may have neglected the more complex how-to and principles knowledge. On the other hand, these campaigns may have tried to address such knowledge, but failed because of existing misconceptions about genetics. Both explanations suggest that future campaigns should first determine the target group's prior knowledge, and then build upon it to increase how-to and principles knowledge, ensuring accurate interpretation of the new information. Although the public may be primarily interested in how-to knowledge, ${ }^{30,31}$ we do suggest not neglecting principles knowledge. Indeed, Seemann ${ }^{50}$ suggested that education should not only focus on the know-how of a subject, but also on the know-why. For present purposes, having accurate knowledge of the underlying mechanisms or principles knowledge substantially increases, but is not necessary to, the proper use of how-to knowledge in decision-making processes and preventive behavior. ${ }^{9}$ Moreover, individuals seem interested in principles knowledge when they deem it personally relevant $^{26}$ and should thus be available. Accurate principles knowledge may also allow for the transfer of this knowledge to other health issues.

Advances in genetic science have provided public health promoters with information about genetic aspects of multifactorial diseases and consequently enabled them to use this information in educating the general public. However, public health promotion has a long way to go concerning public understanding of genetic risk factors and why these factors increase, but do not determine, the risk of developing multifactorial diseases. For now, we may need to mark time and ask ourselves how to effectively educate the general public about the genetic risk factors of multifactorial disease. On the one hand, the complexity of genetic information may lead to misunderstanding and misconceptions which, in turn, may result in the incorrect processing of new information. On the other hand, learning of the existence of genetic risk factors may not only have no effect on preventive behavior, it may indeed have 
adverse effects. Furthermore, too much media attention to genetic risk factors can lead to an overestimation of the impact of such factors ${ }^{28}$ and consequently to an underestimation of the impact of lifestyle on disease development. Such misconceptions may reduce the public's motivation to change their lifestyles in response to information about genetic risk factors.

To conclude, the knowledge framework as suggested by E. M. Rogers proved to be a useful tool in broadening our insight into public knowledge of genetic risk factors. It allowed us to differentiate between knowledge, which grows more complex by degree, in gradual stages. Future research may use this knowledge framework to provide a more detailed overview of the general public's knowledge of genetic risk factors. As genetic knowledge was lower among ethnic minorities and the lower-educated segment of the population, we suggest detailed attention be paid to both the dissemination of genetic knowledge to these segments and their abilities to understand genetic information. However, before using genetic information in public health promotion, we need to understand how such information is processed, how it influences subsequent decision-making, and whether it effectively motivates individuals to engage in preventive behavior. Once we have identified the processes through which knowledge of genetic risk factors successfully influences preventive behavior, information about genetic risk factors, as determined by Rogers' knowledge framework, will be a valuable asset to the public health promotion repertoire.

\section{ACKNOWLEDGMENTS}

This study was financially supported by Maastricht University. It was performed at the School for Public Health and Primary Care (Caphri), a part of the Netherlands School of Primary Care Research (CaRe), which was acknowledged by the Royal Netherlands Academy of Arts and Sciences (KNAW) in 1995. We thank Janaica Grispen for valuable comments on an earlier draft of this article.

\section{References}

1. Collins FS, Green ED, Guttmacher AE, Guyer MS. A vision for the future of genomics research. Nature 2003;422:835-847.

2. World Health Organization. Genomics and world health. Geneva: World Health Organization, 2002.

3. Center for Disease Control. Genetic information presents many new opportunities to improve health and prevent disease. Available at: http://www.cdc.gov/genomics/ population/file/print/opportunity.pdf. Accessed April 19, 2007.

4. Khoury MJ, Thrasher JF, Burke W, Gettig EA, et al. Challenges in communicating genetics: a public health approach. Genet Med 2000;2:198-202.

5. Kardia SL, Wang C. The role of health education and behavior in public health genetics. Health Educ Behav 2005;32:583-588.

6. Prochaska JO, DiClemente CC. The transtheoretical approach: crossing traditional boundaries of therapy. Homewood, IL: Dow Jones-Irwin, 1984.

7. Prochaska JO, DiClemente CC. Stages of change in the modification of problem behaviors. Prog Behav Modif 1992;28:184-218.

8. Weinstein ND. The precaution adoption process. Health Psychol 1988;7:355-386.

9. Rogers EM. Diffusion of innovations, 5th ed. New York: Free Press, 2003.

10. Geibert RC. Using diffusion of innovation concepts to enhance implementation of an electronic health record to support evidence-based practice. Nurs Adm Q 2006; 30:203-210.

11. Kautz K, Larsen EA. Diffusion theory and practice. Disseminating quality management and software process improvement innovations. Inform Tech People 2000;13: $11-26$.
12. Jallinoja P, Aro AR. Does knowledge make a difference? The association between knowledge about genes and attitudes toward gene tests. J Health Commun 2000;5:29-39.

13. Chapple A, May C, Campion P. Lay understanding of genetic disease: a British study of families attending a genetic counseling service. J Genet Couns 1995;4:281-300.

14. van de Nieuwenhoff HWP, Mesters I, Gielen C, de Vries NK. Family communication regarding inherited high cholesterol: why and how do patients disclose genetic risk? Soc Sci Med 2007;65:1025-1037.

15. Khoury MJ. Genetics and genomics in practice: The continuum from genetic disease to genetic information in health and disease. Genet Med 2003;5:261-268.

16. Health Council of the Netherlands. Public awareness about genetics. The Hague: Health Council of the Netherlands, 2003. Report No.: 2003/05.

17. Richards M, Ponder M. Lay understanding of genetics: a test of a hypothesis. J Med Genet 1996;33:1032-1036.

18. Waller J, McCaffery K, Wardle J. Beliefs about the risk factors for cervical cancer in a British population sample. Prev Med 2004;38:745-753.

19. Ackermann S, Renner SP, Fasching PA, Poehls U, et al. Awareness of general and personal risk factors for uterine cancer among healthy women. Eur J Cancer Prev 2005; 14:519-524.

20. Mogilner A, Otten M, Cunningham JD, Brower ST. Awareness and attitudes concerning BRCA gene testing. Ann Surg Oncol. 1998;5:607-612.

21. Tambor ES, Rimer BK, Strigo TS. Genetic testing for breast cancer susceptibility: awareness and interest among women in the general population. Am J Med Genet. 1997;68:43-49.

22. van den Nieuwenhoff HWP, Mesters I, de Vries NK. Public awareness of the existence of inherited high cholesterol. Eur J Cardiovasc Prev Rehabil 2006;13:990-992.

23. Donovan KA, Tucker DC. Knowledge about genetic risk for breast cancer and perceptions of genetic testing in a sociodemographically diverse sample. J Behav Med 2000;23:15-36.

24. Bates BR, Templeton A, Achter PJ, Harris TM, et al. What does 'a gene for heart disease' mean? A focus group study of public understandings of genetic risk factors. Am J Med Genet A 2003;119:156-161.

25. Inoue M, Iwasaki M, Otani T, Sasazuki S, et al. Public awareness of risk factors for cancer among the Japanese general population: a population-based survey. BMC Public Health 2006;6:2.

26. Mesters I, Ausems A, de Vries H. General public's knowledge, interest and information needs related to genetic cancer: an exploratory study. Eur J Cancer Prev 2005;14:69-75.

27. McMenamin M, Barry H, Lennon AM, Purcell H, et al. A survey of breast cancer awareness and knowledge in a Western population: lots of light but little illumination. Eur J Cancer 2005;41:393-397.

28. de Vries H, Mesters I, van de Steeg H, Honing C. The general public's information needs and perceptions regarding hereditary cancer: an application of the Integrated Change Model. Patient Educ Couns 2005;56:154-165.

29. Henneman L, Timmermans DRM, van der Wal G. Public experiences, knowledge and expectations about medical genetics and the use of genetic information. Community Genet 2004;7:33-43.

30. Emery J, Kumar S, Smith H. Patient understanding of genetic principles and their expectations of genetic services within NHS: a qualitative study. Community Genet $1998 ; 1: 78-83$.

31. Hendriks JJJ, de Vries H. Erfelijkheid en kanker: focusgroep interviews naar opvattingen van Nederlanders [Heredity and cancer: focus-group interviews of Dutch opinions]. Maastricht: University of Maastricht, 2002.

32. Honda $\mathrm{K}$. Who gets the information about genetic testing for cancer risk? The role of race/ethnicity, immigration status, and primary care clinicians. Clin Genet 2003;64: $131-136$.

33. Einsiedel EF. The challenges of translating genomic knowledge. Clin Genet 2006;70: 433-437.

34. Chen LS, Goodson P. Public health genomics knowledge and attitudes: a survey of public health educators in the United States. Genet Med 2007;9:496-503.

35. Baars M, Henneman L, ten Kate LP. Deficiency of knowledge of genetics and genetic tests among general practitioners, gynecologists, and pediatricians: a global problem. Genet Med 2005;7:605-610.

36. Baars M, Scherpbier AJJA, Schuwirth LW, Henneman L, et al. Deficient knowledge of genetics relevant for daily practice among medical students nearing graduation. Genet Med 2005;7:295-301.

37. Wonkam A, Njamnshi AK, Angwafo FFI. Knowledge and attitudes concerning med ical genetics amongst physicians and medical students in Cameroon (sub-Saharan Africa). Genet Med 2006;8:331-338.

38. Lerman C, Narod S, Schulman K, Hughes C, et al. BRCA1 testing in families with hereditary breast-ovarian cancer. A prospective study of patient decision making and outcomes. JAMA 1996;275:1885-1892.

39. Lanie AD, Epstein Jayaratne T, Sheldon JP, Kardia SLR, et al. Exploring the public understanding of basic genetic concepts. J Genet Couns 2004;13:305-320.

40. Richards M. Lay and professional knowledge of genetics and inheritance. Public Underst Sci 1996;5:217-230. 


\section{Smerecnik et al.}

41. Renner CH, Renner MJ. But I thought I knew that: using confidence estimation as a debiasing technique to improve classroom performance. Appl Cogn Psychol 2001; 15:23-32.

42. Marteau TM, Lerman C. Genetic risk and behavioural change. BMJ 2001;322:10561059.

43. Bottorff JL, Ratner PA, Balneaves LG, Richardson CG, et al. Women's interest in genetic testing for breast cancer risk: the influence of socidemographics and knowledge. Cancer Epidemiol Biomarkers Prev 2002;11:89-95.

44. Bruno M, Tommasi S, Stea B, Quaranta M, et al. Awareness of breast cancer genetics and interest in predictive genetic testing: a survey of a southern Italian population. Ann Oncol 2004;15(suppl 1):i48-i54.

45. Hunt K, Emslie C, Watt G. Lay constructions of a family history of heart disease: potential for misunderstandings in the clinical encounter? Lancet 2001;357:1168-1171.
46. Keighley MRB, O'Morain C, Giacosa A, Ashorn M, et al. Public awareness of risk factors and screening for colorectal cancer in Europe. Eur J Cancer Prev 2004;13: 257-262.

47. Morris J, Gwinn M, Clyne M, Khoury MJ. Public knowledge regarding the role of genetic susceptibility to environmentally induced health conditions. Community Genet 2003;6:22-28.

48. Wardle J, Waller J, Brunswick N, Jarvis MJ. Awareness of risk factors for cancer among British adults. Public Health 2001;115:173-174.

49. Welkenhuysen M, Evers-Kiebooms G, Decruyenaere M, Claes E, et al. A community based study on intentions regarding predictive testing for hereditary breast cancer. J Med Genet 2001;38:540-547.

50. Seemann K. Basic principles of holistic technology education. J Technol Educ 2003 $14: 28-39$. 